(C) S. A. SVETOV, S. I. CHAZHENGINA, * V. K. SINGH,**

Z. P. RYBNIKOVA, ${ }^{*}$ S. MISHRA***

\title{
ACCESSORY ZONED CHROMITE FROM ARCHEAN KOMATIITES OF THE KARELIAN CRATON, RUSSIA: METAMORPHIC FINGERPRINTS
}

\author{
* Institute of Geology, Karelian Research Centre RAS, \\ Pushkinskaya St., 11, Petrozavodsk, 185910, Russia; \\ e-mail: chazhengina@mail.ru \\ ** Department of Geology, Bundelkhand University, Jhansi, India \\ *** Department of Geology, Hemvati Nandan Bahuguna Garhwal University, \\ Srinagar-Garhwal, India
}

SEM and LA-ICP-MS analyses were used for the study of accessory chromite in Archean (3.0$2.8 \mathrm{Ga}$ ) komatiites from the most representative greenstone belts of the Karelian Craton. Zoned chromite, subjected to varying degrees of metamorphic alteration, was identified in the komatiites. Two types of zoned chromite, differing in the composition of their cores, were recognized. Al-rich zoned chromite of type I shows the low extent of metamorphic alteration and has cores with $\mathrm{Cr} \#$ $0.70-0.86, \mathrm{Mg} \# 0.03-0.12$, and Fe\# $0.06-0.23$. It is enriched in $\mathrm{Zn}, \mathrm{Co}$, and $\mathrm{Mn}$ but strongly depleted in $\mathrm{Ga}, \mathrm{Ni}$, and $\mathrm{V}$. The study reveals that the primary magmatic distribution of minor and trace elements in the cores was strongly redisturbed during prograde metamorphism of greenschist to low amphibolite facies. Zoned chromite with the low $\mathrm{Al}_{2} \mathrm{O}_{3}$ content of type II has cores with higher Fe\# (0.42 - 0.49), Cr\# (0.88-1), and lower $\mathrm{Mg} \#(0-0.04)$ as compared to cores of Al-rich chromite, that corresponds to the more intensive metamorphic alteration. Since the primary composition of studied zoned chromite was significantly obliterated during metamorphism, established patterns can be used as a guide for the reconstruction of metamorphic processes.

Key words: zoned chromite, minor and trace elements, komatiites, Archean, Karelian Craton.

\section{C. А. СВЕТОВ,* д. чЛ. С. И. ЧАЖЕНГИНА, C. МИСХРА.*** АКЦЕССОРНЫЙ ЗОНАЛЬНЫЙ ХРОМИТ \\ ИЗ АРХЕЙСКИХ КОМАТИИТОВ КАРЕЛЬСКОГО КРАТОНА, РОССИЯ: ПРИЗНАКИ МЕТАМОРФИЧЕСКИХ ПРЕОБРАЗОВАНИЙ \\ * Геологический институт Кольского научного иентра РАН, Апатиты, Россия \\ ** Университет Бунделкханд, факультет геологии, Джхханси, Индия \\ *** Гархвальский университет им. Хемвати Нандан Бахугуна, факультет геологии, \\ Шринагар, Индия}

В работе представлены результаты изучения акцессорного хромита из архейских коматиитов (3.0-2.8 млрд лет) наиболее типичных зеленокаменных структур Карельского кратона. Выделено два типа зонального хромита, различающихся по составу и степени метаморфических преобразований. Показано, что первичный состав хромита почти нацело преобразован в ходе проградного метаморфизма зеленосланцевой и эпидот-амфиболитовой фаций.

Ключевые слова: зональный хромит, редкие и примесные элементы, коматииты, архей, Карельский кратон.

\section{INTRODUCTION}

Chromite $\left(\mathrm{Fe}^{2+}, \mathrm{Mg}\right)\left(\mathrm{Cr}, \mathrm{Al}, \mathrm{Fe}^{3+}\right)_{2} \mathrm{O}_{4}$ is a common accessory mineral in mafic and ultramafic rocks, which has the distinct and diverse composition reflected the parental melt composition (Dick, Bullen, 1984; Barnes, Kunilov, 2000; Kamenetsky et al., 2001, and references therein). Accessory chromite has proved to be a reliable 
petrological indicator in Phanerozoic tholeiitic and boninitic lavas (Barnes, 1998; Page et al., 2012), Neoproterozoic serpentinites (Burkhard, 1993; Farahat, 2008), and Archean komatiites (Zhou, Kerrich, 1992; Barnes 1998; Arndt et al., 2008).

A crucial point in the studies of Archean mafic and ultramafic rocks, including komatiites, is that the primary mineral parageneses have been considerably modified by metamorphic alteration (Hanski, 1980; Barnes, 2000; Smolkin et al., 2000; Svetov et al., 2001; Arndt et al., 2008). In such cases, melt generation conditions or tectonic provenance can be reconstructed either based on the chemical composition of the bulk rocks, utilizing immobile element behaviour (Polat, Kerrich, 2006; Arndt et al., 2008; Manikyamba et al., 2008), or using chemical data on relics of primary minerals, e. g. accessory chromite which is commonly the only primary mineral preserved in komatiites.

However, the primary composition of accessory chromite can be substantially modified during post-crystallization metamorphic processes (Barnes, 1998; Gervilla et al., 2012; Colas et al., 2014; Gonzalez-Jiménez et al., 2016), that complicates the identification of primary chromite relics and their petrogenetic interpretation. Recent studies of chromite (Colas et al., 2014; Gonzalez-Jiménez et al., 2016) show that the application of its major element composition as an indicator of magmatic processes have to be combined with the analysis of minor elements providing the careful evaluation of metamorphic effects.

The metamorphic alteration of chromite depends on a number of factors, including the type of the protolith, $P-T$ conditions and duration of metamorphism, and the composition of fluids (Barnes, 2000; Farahat, 2008; Gervilla et al., 2012; Colas et al., 2014; Gonzalez-Jiménez et al., 2016). The studies of chemical and textural modifications of chromite during metamorphic transformation reveal that relics of primary chromite can be well preserved in rocks metamorphosed under greenshist to low amphibolite facies (Barnes, 2000; Proenza et al., 2004; Arndt et al., 2008; Farah et al., 2008; Colas et al., 2014; Gonzalez-Jiménez et al., 2016). Wherein, chromite from metamorphosed chromitites preserves primary relics better than accessory chromite (Proenza et al., 2004).

Investigations of ultramafic volcanic rocks in Precambrian complexes of the Fennoscandian Shield have a long history, mainly focused on the research of rock chemistry and petrology (Vrevsky, 1989; Puchtel et al., 1998; Smolkin et al., 2000; Kulikov et al., 2011). The data on Archean primary chromite are fragmentary and their petrogenetic interpretation is insufficient. To the best of our knowledge, only relics of primary chromite were identified by Liipo et al. (1995) in the Archean Näätäniemi serpentinites from the Kuhmo Greenstone Belt, Finland.

To address this shortcoming, we present the results of studying major, minor, and trace element composition of accessory chromite from Archean komatiites in the eastern Fennoscandia.

\section{GEOLOGICAL BACKGROUND}

Komatiitic associations formed in the Precambrian over a wide time range with several global maxima at 3.5-3.3, 3.1-2.6, and 2.4-1.9 Ga (Isley, Abbott, 1999; Abbott, Isley, 2002). In the Fennoscandian Shield, high-Mg (komatiitic) volcanism occurred at 3.0-2.9, 2.9-2.8, and 2.8-2.7 Ga (Vrevsky, 1989). Archean komatiites from the Fennoscandian Shield have been studied in the Kuhmo-Tipasjarvi-Suomussalmi Greenstone Belt, Central Finland (Hanski, 1980; Maier et al., 
2013), the Sumozero-Kenozero, Vedlozero-Segozero, Gimoly-Kostomuksha and other Greenstone Belts, Russian Karelia (Arndt et al., 2008; Puchtel et al., 1998; Svetov, Huhma, 1999; Svetov et al., 2001), and Kolomozero-Voronie Greenstone Belt in the Kola Peninsula (Vrevsky, 1989; Smolkin et al., 2000).

The 3.0-2.9 Ga komatiitic-basaltic series is represented by strata-bound rock sequences, composed of massive, pillowed and variolitic lavas alternating with tuffs, volcano-sedimentary, and terrigenous material. The thickness of the series is varies from 900 to $2000 \mathrm{~m}$ (Svetova, 1988; Svetov, 2005). Komatiites form successions of lava flows 50 to $600 \mathrm{~m}$ thick. Massive and differentiated komatiitic lavas with $\mathrm{MgO}$ contents in the 18-26 wt \% range and width of 5 to $40 \mathrm{~m}$ are widespread. The komatiitic rocks were affected by metamorphism of greenschist to low amphibolite facies at pressure of $c a$. $2-4 \mathrm{kbar}$ and temperature $<600{ }^{\circ} \mathrm{C}$ (Slabunov et al., 2006). Komatiites contain only metamorphic minerals in place of their precursors, that's why their mineral assemblages consist of mainly amphiboles (tremolite, actinolite) and chlorites, accessory chromite, magnetite, and ilmenite, scare talc and carbonates.

The present study was aimed to research accessory chromite from Archean komatiites in the most representative greenstone belts (GSB) of the Karelian Craton: Vedlozero-Segozero (Sovdozero, Palaselga, Hautavaara, and Koykary areas, Central Karelia, 3.0-2.9 Ga), Gimoly-Kostomuksha (Kostomuksha structure, north-eastern Karelia, 2.9-2.8 Ga), Northen Karelian (Hisovaara area, eastern Finland, 2.8-2.7 Ga), and Kuhmo (Siivikkovaara area, eastern Finland, 2.85$2.79 \mathrm{Ga}$ ) (Fig. 1). Zoned chromite, which preserves its primary features, was identified only in Vedlozero-Segozero, Gimoly-Kostomuksha, and Kuhmo. The rock samples retaining zoned chromite were collected primarily from central massive zones and upper portions of mesoaccumulative zones of thinly differentiated lava flows from these areas. The zoned chromite is scarce in either top-flow and lower cumulative zones of lava bodies.

The Vedlozero-Segozero GSB is located in the central part of the Karelian Craton and extends in sub-meridian direction over a distance of approximately $300 \mathrm{~km}$ with width of $50-60 \mathrm{~km}$. It consists of several local domains in which the series of volcano-sedimentary rocks with the maximum thickness up to $6 \mathrm{~km}$ occur within the Neoarchean granitoid rocks (Svetov et al., 2001). Sovdozero and Hautavaara areas are placed at the western margin of the Paleoarchean Vodlozero block, Central Karelia.

The Kostomuksha area includes $2.9-2.8$ Ga komatiites that represented by autobreccia, massive and pillow lavas, and tuffs. Detailed geological background is presented in (Puchtel et al., 1998).

The Siivikkovaara area contains $2.85-2.79$ Ga komatiites and komatiitic basalts that represented by massive, differentiated, and pillowed lavas. Geology is described in detail elsewhere (Hanski, 1980; Huhma et al., 2012).

\section{ANALYTICAL METHODS}

Major and minor elements in chromite were analyzed using a VEGA II LSH (Tescan) scanning electron microscope with an INCA Energy 350 (Oxford instruments) energy dispersive microanalyzer at the following parameters: W-cathode, a voltage of $20 \mathrm{~kW}$ and a spectrum setting time at analytical points of $90 \mathrm{sec}$ in a standard experiment. Determination of chromite composition (over 500 analyses) 


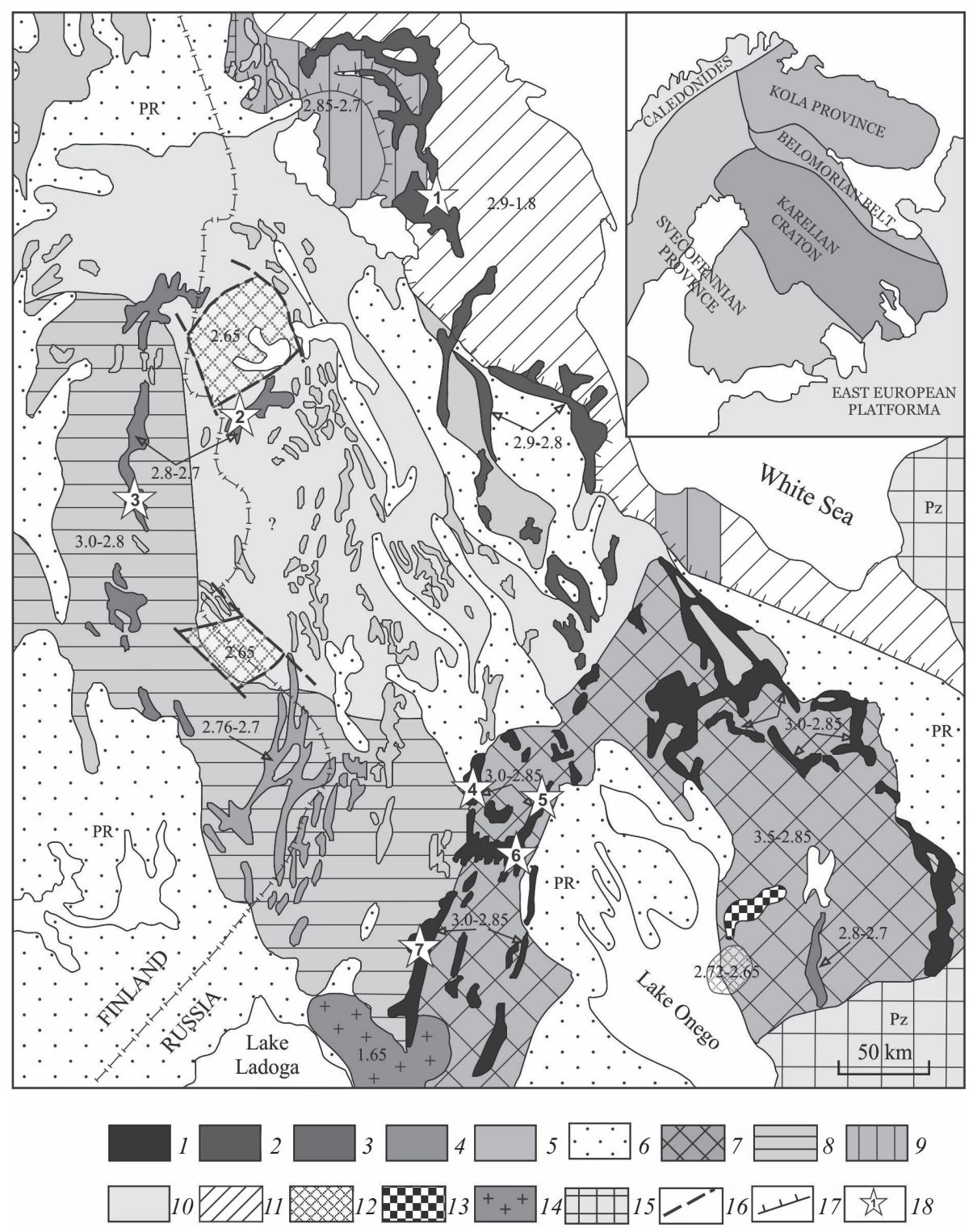

Fig. 1. Geological sketch map of the Karelian Craton (modified after Kozhevnikov, 2000).

$1-5$ - Archean GSB with the age $>3.0-2.9$ Ga (1), 2.9-2.8 Ga (2), 2.8-2.7 Ga (3), <2.75 Ga (4), not determined (5); 6 - Paleoproterozoic subcrustal rocks; 7-10 - Archean crust with the age 3.5-2.85 Ga (7), 3.0-2.8 Ga (8), 2.85-2.7 Ga (9), not determined (10); 11 - Belomorian Mobile Belt; 12 - highly metamorphosed complexes; 13 - Burakovka pluton; 14 - Salma rapakivi granites; 15 - Paleozoic complexes; 16 - thrusts and faults; $17-$ shear zone between Belomorian Mobile Belt and Karelian craton; 18 - studied GSB structures: 1 - Hiisovaara, 2 - Kostomuksha, 3 - Siivikkovaara, 4 - Sovdozero, 5 - Palaselga, 6 - Koikary, 7 - Hautavaara. Numbers in the map indicate ages of geological complexes $(\mathrm{Ga})$.

Рис. 1. Геологическая схема Карельского кратона [по В. Кожевникову (2000) с изменениями].

$1-5$ - архейские зеленокаменные пояса с возрастом $>3.0-2.9 \mathrm{Ga}(1), 2.9-2.8 \mathrm{Ga}(2), 2.8-2.7 \mathrm{Ga}(3),<2.75 \mathrm{Ga}$ (4), неопределенным (5); 6 - палеопротерозойские супракрустальные породы; 7-10 - архейская кора с возрастом 3.5-2.85 Ga (7), 3.0-2.8 Ga (8), 2.85-2.7 Ga (9), неопределенным (10); 11 - Беломорский подвижный пояс; 12 - высокометамофизованные комплексы; 13 - Бураковкий плутон; 14 - Салминский массив гранитов рапакиви; 15 - палеозойские комплексы; 16 - разломы и тектонические зоны; 17 - шир-зоны между Беломорским подвижным поясом и Карельским кратоном; 18 - исследованные зеленокаменные структуры: Хизоваарская (1), Костомукшская (2), Сиивиковаарская (3), Совдозерская (4), Паласельгинская (5), Койкарская (6), Хаутаваарская (7). 
was carried out on the microprobe-quality petrographic thin sections. Mineral formulae were calculated using a MINAL software (developed by D. V. Dolivo-Dobrovolsky).

The minor and trace elements compositions of zoned chromite were determined using New Wave UP 266 laser system connected to an X Series 2 Thermo Fisher Scientific ICP-MS in the Analitical Centre of the Institute of Geology, Karelian Research Centre, RAS. The chromite analysis was focused on the following masses: ${ }^{45} \mathrm{Sc},{ }^{47} \mathrm{Ti},{ }^{51} \mathrm{~V},{ }^{55} \mathrm{Mn},{ }^{59} \mathrm{Co},{ }^{60} \mathrm{Ni},{ }^{66} \mathrm{Zn}$, and ${ }^{71} \mathrm{Ga}$. The LA-ICP-MS analyses were conducted using the $30-70 \mu \mathrm{m}$ beam diameter, $10 \mathrm{~Hz}$ frequency, and $0.13 \mathrm{~mJ} / \mathrm{pulse}$ power. The instrument was calibrated against the NIST 612 silicate glass (National Institute Standard and Technology, Gaithersburg, USA). Aluminum values obtained by electron microprobe were used as the internal standard.

\section{CHROMITE MORPHOLOGY}

The chromite abundance in the studied komatiites is less than 2 vol \%. Several generations of accessory chromite, differing in their textural features, were distinguished by optical microscopy and scanning electron microscopy (SEM).

The early generation is present by either subhedral chromite crystals with a grain size of $0.07-3 \mathrm{~mm}$ or, less commonly, by multi-aggregate clusters of xenomorphic crystals with chicken wire texture. Some grains of this generation are characterized by optically distinguished concentric zoning (Fig. 2, $a-f$ ). They are most abundant in Sovdozero and Kostomuksha komatiites and less common in Hautavaara and Siivikkovaara komatiites. The minimum core size was observed in Hautavaara and Sovdozero komatiites to be $c a .30 \mu \mathrm{m}$ (Fig. 2, b,e) and the maximum core size was
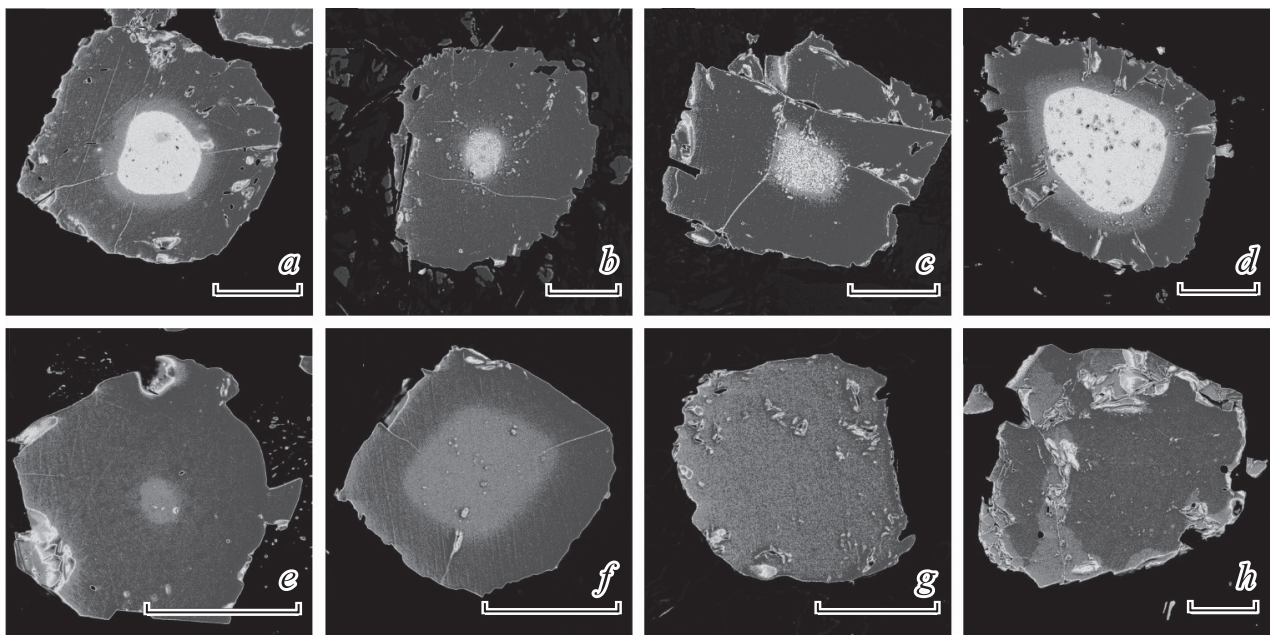

Fig. 2. BSE images of chromite form Archean komatiites: type I zoned chromite from Sovdozero $(a)$, Hautavaara $(b)$, Kostomuksha $(c)$ and Siivikkovaara $(d)$; type II zoned chromite from Sovdozero $(e)$ and Siivikkovaara $(f)$; Cr-rich magnetite from Hautavaara $(g)$ and Kostomuksha $(h)$. Scale bar corresponds to $50 \mu \mathrm{m}$.

Рис. 2. Электронно-микроскопические изображения хромита из архейских коматиитов: зональный хромит I типа из Совдозерской $(a)$ Хаутаваарской $(b)$, Костомукшской $(c)$ и Сиивиковаарской $(d)$ структур; зональный хромит II типа из Совдозерской $(e)$ и Сиивиковаарской $(f)$ структур; хром-магнетит из Хаутаваарской $(g)$ и Костомукшской $(h)$ структур. Масштабная линейка соответствует 50 мкм. 
recorded in Siivikkovaara komatiites to be $c a .90 \mu \mathrm{m}$ (Fig. 2, $d, f$ ). The cores are not always well preserved, especially in Kostomuksha komatiites, in which core fragments are typically observed. Chromite rims vary in thickness from $45 \mu \mathrm{m}$ in Siivikkovaara to $100 \mu \mathrm{m}$ in Hautavaara and Kostomuksha komatiites. SEM images indicate the occurrence of the 10 to $20 \mu \mathrm{m}$ wide transitional zone at the margins of cores for some zoned chromite (Fig. 2, $a-d$ ). The zoned chromite, especially at their rims, is cut by microscopic fractures, filled by actinolite, tremolite, and chlorites.

Apart from the zoned chromite, $80-150 \mu \mathrm{m}$ subhedral to anhedral unzoned grains of Cr-rich magnetite were identified in all studied komatiites (Fig. 2, $g, h$ ).

The late metamorphic generation, the most abundant in studied komatiites, is presented by fine $(1-10 \mu \mathrm{m})$ euhedral crystals of magnetite.

\section{CHROMITE CHEMISTRY}

Major elements. Two types of zoned chromite, differing in the composition of their cores, were identified: 1) type I chromite with Al-rich cores (Fig. 2, $a-d$ ), and 2) type II chromite with Al-poor ones (Fig. 2, $e-f$ ).

Type I zoned chromite has cores which contain $\mathrm{Cr}_{2} \mathrm{O}_{3}\left(44.8-53.3\right.$ wt \%), $\mathrm{Al}_{2} \mathrm{O}_{3}$ (5.6-13.8 wt \%), $\mathrm{MgO}(0.4-2.3 \mathrm{wt} \%)$, total iron (30.3-37.2 wt \%) (Table 1). The cores are characterized by $\mathrm{Cr} \#[\mathrm{Cr} /(\mathrm{Cr}+\mathrm{Al})$ atomic ratio $] 0.69-0.86$, with maximum values for chromite from the Kostomuksha area, $\mathrm{Mg} \#\left[\mathrm{Mg} /\left(\mathrm{Mg}+\mathrm{Fe}^{2+}\right)\right.$ atomic ratio] $0.03-0.12$, and $\mathrm{Fe} \#\left[\mathrm{Fe}^{3+} /\left(\mathrm{Fe}^{3+}+\mathrm{Fe}^{2+}\right)\right.$ atomic ratio $] 0.06-0.23$. The cores are surrounded by 10 to $20 \mu \mathrm{m}$ wide transitional zone, formed by ferrian chromite (Fig. 2, $a-d$ ). Its composition is enriched in total iron and slightly depleted in $\mathrm{Cr}_{2} \mathrm{O}_{3}$, whereas the $\mathrm{Al}_{2} \mathrm{O}_{3}$ content dramatically drops down relatively to the core (Fig. 3, $a-d$ ). This is reflected in higher $\mathrm{Cr} \#(0.76-0.99)$, and $\mathrm{Fe \#}$ $(0.25-0.46)$. The $\mathrm{MgO}$ content in the transitional zone is similar or slightly lower than in the core. The only exception is the chromite from the Kostomuksha area, for which the $\mathrm{MgO}$ content seems not to change from the core to their rims. Type I zoned chromite rims show the increase of total iron content and decrease of $\mathrm{Cr}_{2} \mathrm{O}_{3}$ content towards grain margins (Fig. $3, a-d ; 4)$. Fe\# $(0.44-0.66)$ is higher in rims than in the core and transition zone. The $\mathrm{MgO}$ content in rims is extremely low (Mg\# 0.0-0.05) as compared to the core. Also the type I zoned chromite shows an overall trend of decreasing $\mathrm{Cr}_{2} \mathrm{O}_{3}$ and $\mathrm{Al}_{2} \mathrm{O}_{3}$ contents and increasing the total iron content from the core to its rims (Fig. 3, $a-d ; 4$ ).

The cores of type II zoned chromite have high contents of total iron (53.262.8 wt \%) and $\mathrm{Cr}_{2} \mathrm{O}_{3}\left(31.8-49.1\right.$ wt \%), and extremely low content of $\mathrm{Al}_{2} \mathrm{O}_{3}$ $(0.3-0.8$ wt \%) (Table 2). Thus, the cores show higher Fe\# $(0.42-0.49)$ and $\mathrm{Cr} \#$ $(0.88-1.0)$, and lower Mg\# $(0.0-0.04)$ than cores of type I zoned chromite, that is closed to the composition of transitional zone of type I zoned chromite. The chemical changes in rims surrounding type II chromite cores are similar to rims of type I zoned chromite, appearing in decrease of $\mathrm{Cr}_{2} \mathrm{O}_{3}$ content and increase of $\mathrm{FeO}_{\text {tot }}$ towards the margins of grains (Fig. 3, e, f).

Additionally, $\mathrm{Cr}$-rich magnetite has the lower $\mathrm{Cr}_{2} \mathrm{O}_{3}$ content $(14.1-27.1 \mathrm{wt} \%)$ and the similar content of $\mathrm{Al}_{2} \mathrm{O}_{3}$ and $\mathrm{MgO}$, as compared to cores of type II zoned chromite (Table 2). The majority of its grains are characterized by decrease of the $\mathrm{Cr}_{2} \mathrm{O}_{3}$ content from the center to rims, along with the stable $\mathrm{Al}_{2} \mathrm{O}_{3}$ and $\mathrm{MgO}$ contents (Fig. 2, $g, h$ ). 


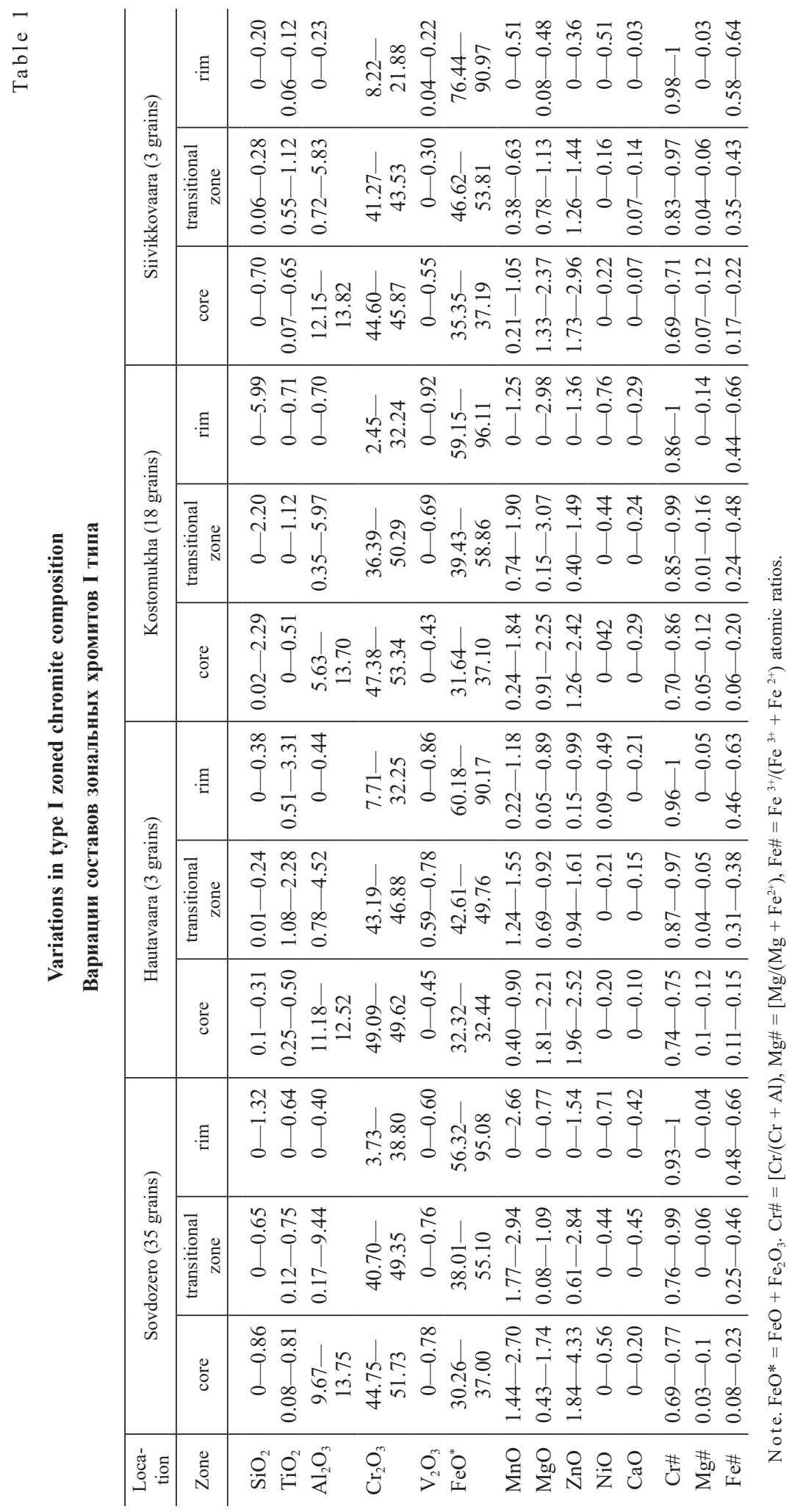



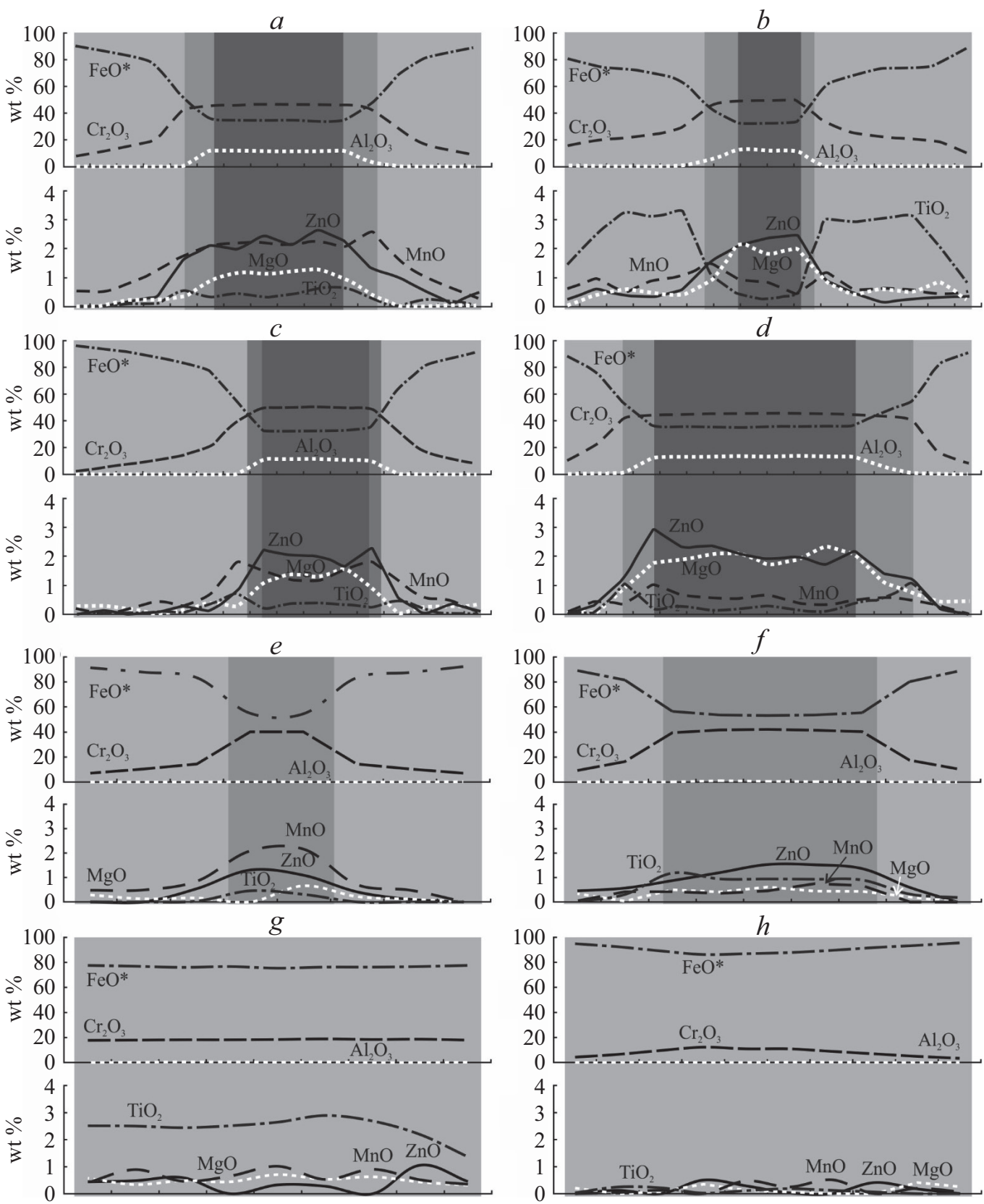

Fig. 3. Quantitative microprobe profiles across the chromite grains, shown on Fig. 2: type I zoned chromite from Sovdozero $(a)$, Hautavaara $(b)$, Kostomuksha $(c)$, and Siivikkovaara $(d)$; type II zoned chromite from Sovdozero $(e)$ and Siivikkovaara $(f)$; Cr-rich magnetite from Hautavaara $(g)$ and Kostomuksha $(h)$. Dark grey color marks cores of type I zoned chromite, grey - transitional zone of type I zoned chromite or center of type II zoned chromite, light grey — rims.

Рис. 3. Микрозондовые профили через зерна хромита, показанные на рис. 2: зональныый хромит I типа из Совдозерской $(a)$ Хаутаваарской $(b)$, Костомукшской $(c)$ и Сиивиковаарской $(d)$ структур; зональный хромит II типа из Совдозерской $(e)$ и Сиивиковаарской $(f)$ структур; хром-магнетит из Хаутаваарской $(g)$ и Костомукшской $(h)$ структур. Темно серым иветом обозначены ядра хромита I типа, серым - переходная зона хромита I типа или ядра хромита II типа, светло серым каймы. 


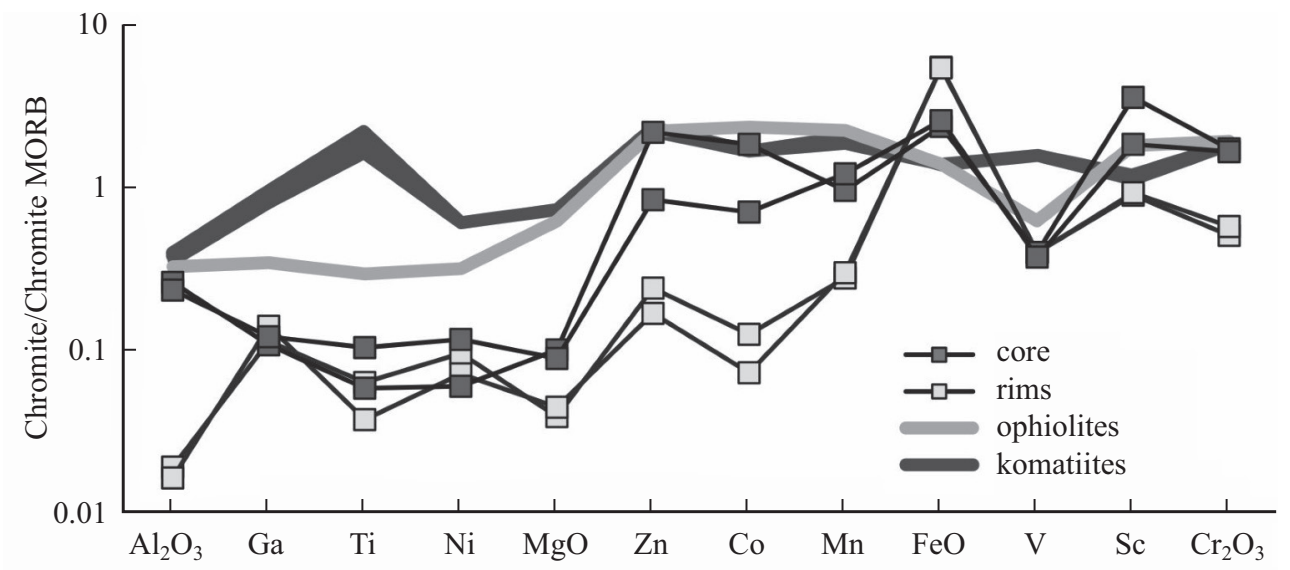

Fig. 4. Spidergrams of major and trace elements for the core and rims of type I zoned chromite from the Kostomuksha area, compared with unmetamorphosed chromite from ophiolites (after Pagé, Barnes, 2009) and komatiites (after Gonzalez-Jiménez et al., 2014). Concentrations of elements are normalized to the composition of chromite from MORB (Pagé, Barnes, 2009).

Рис. 4. Спайдер-диаграммы макро- и микроэлементов в ядре и кайме зонального хромита I типа из Костомукшской структуры в сравнении с неметаморфизованным хромитом из офиолитов (Раgé, Barnes, 2009) и коматиитов (Gonzalez-Jiménez et al., 2014). Содержания элементов нормализованы по составу хромита из MORB (Pagé, Barnes, 2009).

Table 2

Variations in type II zoned chromite composition

Вариации составов зональных хромитов II типа

\begin{tabular}{c|c|c|c|c|c|c}
\hline $\begin{array}{c}\text { Loca- } \\
\text { tion }\end{array}$ & \multicolumn{2}{|c|}{ Sovdozero (2 grains) } & \multicolumn{2}{c|}{ Kostomukha (4 grains) } & \multicolumn{2}{c}{ Siivikkovaara (2 grains) } \\
\hline $\mathrm{Zone}$ & centre & rim & \multicolumn{2}{c|}{ core } & rim & \multicolumn{2}{|c}{ centre } & rim \\
\hline $\mathrm{SiO}_{2}$ & $0-0.50$ & $0.13-0.43$ & $0.09-1.02$ & $0-0.18$ & $0-0.13$ & $0-0.31$ \\
$\mathrm{TiO}_{2}$ & $0.27-0.46$ & $0-0.20$ & $0.68-1.07$ & $0-0.19$ & $0.74-0.95$ & $0.01-0.18$ \\
$\mathrm{Al}_{2} \mathrm{O}_{3}$ & $0.25-0.34$ & $0-0.29$ & $0.48-1.09$ & $0-0.15$ & $0.58-0.77$ & $0-0.16$ \\
$\mathrm{Cr}_{2} \mathrm{O}_{3}$ & $40.08-42.42$ & $6.80-7.02$ & $31.78-42.41$ & $3.65-11.07$ & $35.27-42.11$ & $7.72-10.59$ \\
$\mathrm{~V}_{2} \mathrm{O}_{3}$ & $0.29-0.48$ & $0.03-0.26$ & $0.51-0.94$ & $0.28-0.46$ & $0.06-0.28$ & $0.13-0.25$ \\
$\mathrm{FeO}$ & $52.15-55.11$ & $91.39-92.26$ & $51.71-62.79$ & $86.93-95.36$ & $53.26-60.93$ & $88.53-90.93$ \\
$\mathrm{MnO}$ & $1.74-2.44$ & $0-0.48$ & $0.75-1.71$ & $0-0.29$ & $0.46-0.56$ & $0-0.18$ \\
$\mathrm{MgO}$ & $0-0.66$ & $0-0.48$ & $0.37-0.88$ & $0-0.21$ & $0.55-0.61$ & $0-0.45$ \\
$\mathrm{ZnO}$ & $1.06-1.31$ & $0-0.24$ & $0.13-1.11$ & $0-0.58$ & $0.92-1.54$ & $0-0.45$ \\
$\mathrm{NiO}$ & $0-0.48$ & $0-0.31$ & $0-0.21$ & $0-0.58$ & $0-0.25$ & $0.14-0.40$ \\
$\mathrm{CaO}$ & $0-0.14$ & $0-0.24$ & $0-0.13$ & $0.1-0.27$ & $0-0.01$ & $0-0.1$ \\
$\mathrm{Cr} \#$ & $0.99-1$ & $0.99-1$ & $0.96-0.98$ & $0.95-1$ & $0.97-0.98$ & $0.97-1$ \\
$\mathrm{Mg} \#$ & $0-0.04$ & $0-0.02$ & $0.02-0.05$ & $0-0.01$ & $0.03-0.04$ & $0-0.02$ \\
$\mathrm{Fe} \#$ & $0.46-0.48$ & 0.64 & $0.42-0.48$ & $0.63-0.66$ & $0.42-0.49$ & $0.63-0.64$
\end{tabular}


Minor and trace elements. The microprobe analyses indicate that cores of zoned chromite of type I and II are enriched in $\mathrm{ZnO}$ and $\mathrm{MnO}$. Moreover, cores of type I zoned chromite have the slightly higher content of $\mathrm{ZnO}(1.3-4.3 \mathrm{wt} \%)$, as compared with cores of type II zoned chromite $(1.1-2.3 \mathrm{wt} \%)$, while $\mathrm{MnO}$ $(0.5-2.7 \mathrm{wt} \%)$ and $\mathrm{NiO}$ (up to $0.6 \mathrm{wt} \%)$ contents are similar in cores of zoned chromite of both types (Table 1,2). Spatial distribution of these elements in cores is homogenous. Zoned chromite of type I and II is characterized by the decrease of $\mathrm{ZnO}$ and $\mathrm{MnO}$ contents from the core to rims (Fig. 3, a-f). In contrast, the rims are enriched in $\mathrm{NiO}$ relatively to the core. $\mathrm{The}^{\mathrm{TiO}}{ }_{2}$ content is closed to be uniform from the core to rims with a slight increase in the transition zone for type I chromite or in cores for type II chromite. The only exception is type I zoned chromite from Hautavaara with an extreme enrichment in $\mathrm{TiO}_{2}$ in its rims (Fig. 3, b). The $\mathrm{V}_{2} \mathrm{O}_{3}$ content is slightly variable and similar both in the core and rims. Cr-magnetite is depleted in $\mathrm{ZnO}(0.0-1.2 \mathrm{wt} \%)$ and $\mathrm{MnO}(0.0-1.1 \mathrm{wt} \%)$ (Table 1).

Because of the small size of zoned chromite grains the LA-ICP data were obtained only for Al-rich zoned chromite from Kostomuksha. Fig. 4 shows spidergrams of major and trace elements for the core and rims of that chromite which follow plots drawn by Pagé and Barnes (2009) for ophiolites and komatiites. Cores of zoned chromite are strongly enriched in $\mathrm{Zn}, \mathrm{Co}, \mathrm{Mn}$, and Sc, and depleted in $\mathrm{Ga}, \mathrm{Ti}, \mathrm{Ni}$, and $\mathrm{V}$. The core pattern shows the negative $\mathrm{V}$ anomaly and positive $\mathrm{Sc}$ anomaly. Rims of zoned chromite have the similar $\mathrm{Ga}, \mathrm{Ti}, \mathrm{Ni}$, and $\mathrm{V}$ content, as compared to its cores. Moreover, the rims pattern is also characterized by the negative $\mathrm{V}$ anomaly and positive Sc anomaly. However, the rims are strongly depleted in $\mathrm{Zn}, \mathrm{Co}, \mathrm{Mn}$ in contrast to the cores.

\section{DISCUSSION}

Are there any relics of primary chromite? Archean komatiites from the Karelian Craton retain two types of zoned chromite with the Al-rich and Al-poor cores. Zoned chromite grains are predominantly subhedral and have the relatively curved and lobate phase boundary between core and rims. This textural pattern suggests that the zoning appears due to the alteration of primary chromite.

In the $\mathrm{Cr}-\mathrm{Al}-\mathrm{Fe}^{3+}$ ternary diagram (Fig. 5) the core compositions of Al-rich zoned chromite (type I) from the studied areas fall into the field of primary chromite metamorphosed in the amphibolite facies at temperature ranging from 500 to $550{ }^{\circ} \mathrm{C}$. The core compositions of type II chromite plot in the field of ferrian chromite. The data are constituent with temperatures of regional metamorphism determined for the studied Archean komatiites (Svetov, 2005; Slabunov et al., 2006). $\mathrm{S}$. Barnes (2000) proposed that these temperatures are closed to the limiting conditions, where the primary magmatic chromite composition might be substantially modified by metamorphic processes.

Variations in the composition of rims for zoned chromite of both types show the trend of $\mathrm{Cr}^{3+}$ decreasing and $\mathrm{Fe}^{3+}$ increasing from the inner to outer zones of rims, that is constituent with the ferrian chromite and Cr-magnetite formation (Fig. 5). The small miscibility gap between cores and rims indicates that cores are closed to the equilibrium with rims and, consequently, do not completely preserve primary compositions. These conclusions suppose that even the composition of the mostly well preserved cores of type I zoned chromite is partially obliterated by alter- 


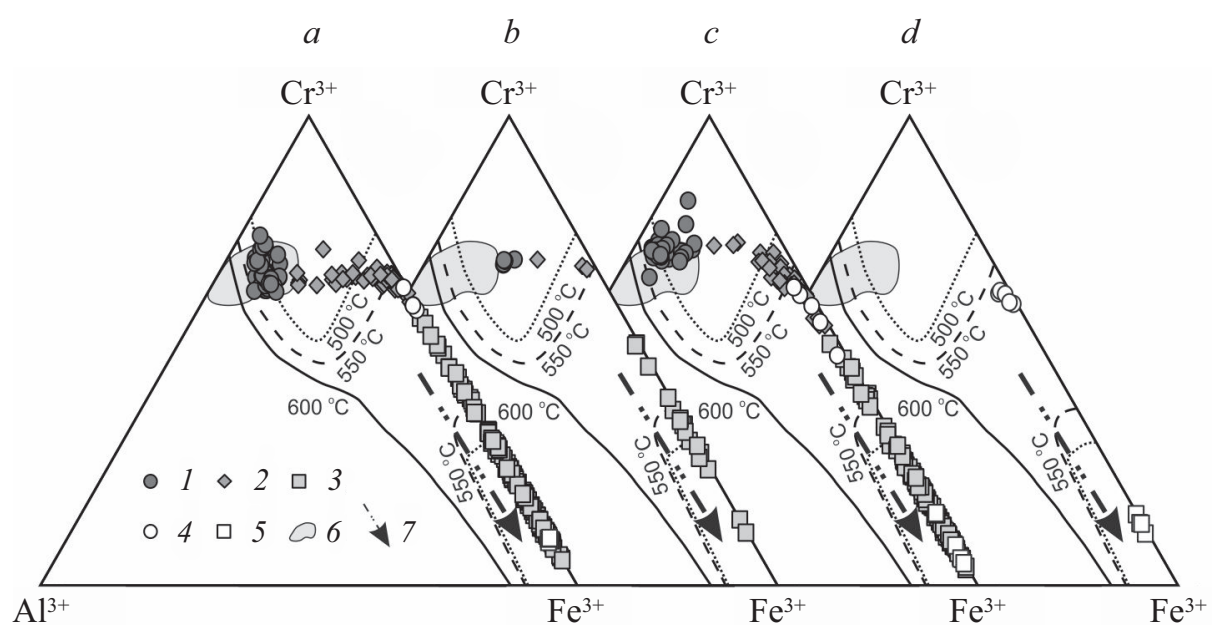

Fig. 5. Composition of zoned chromite from Sovdozero (a), Hautavaara (b), Kostomuksha (c), and Siivikkovaara $(d)$ with reference to the solvus determined at 500,550 and $600{ }^{\circ} \mathrm{C}$ by Sack and Ghiorso (1991) for chromite coexisting with olivine containing $90 \%$ of forsterite.

1 - core , 2 - transitional zone, 3 - rims of type I zoned chromite; 4 - core, 5 - rims of type II zoned chromite; 6 - field of greenshist primary chromite plotted after Barnes (2000); 7 - direction from inner to outer zones of the rims.

Рис. 5. Составы зонального хромита из архейских коматиитов восточной части Фенноскандии из Совдозерской $(a)$, Хаутаваарской $(b)$, Костомукшской $(c)$ и Сиивиковаарской $(d)$ структур. Кривая сольвуса построена (Sack, Ghiorso, 1991) для температур 500, 550 и $600{ }^{\circ} \mathrm{C}$ для хромита равновесного с оливином, содержащим 90 \% форстеритового минала.

ation. Only contents of trivalent cations $\mathrm{Al}^{3+}$ and $\mathrm{Cr}^{3+}$ seem to remain relatively unchanged in these relict cores. It is evidenced by low Fe\# $(0.08-0.22)$ and high $\mathrm{Cr} \#$ $(0.69-0.86)$, which are close to the "primary," pre-metamorphic values. However, cores of type I chromite indicate significant modifications with regard to divalent cation e. g., $\mathrm{Mg}^{2+}$ and $\mathrm{Zn}^{2+}$. The low $\mathrm{Mg \#}(0.01-0.14)$ argues strongly that Al-rich zoned chromite is significantly altered and only partially preserves the signatures of primary magmatic chromite. The relict cores of type II chromite are represented by ferrian chromite that suggest the its primary composition has been obliterated to the larger extent than the composition of cores of type I chromite.

On the basis of these observations, textural and chemical characteristics of the studied zoned chromite of Archean komatiites from the Karelian Craton are comparable to that of altered chromite from metamorphosed komatiite in the low to mid-amphibolite facies (Liipo et al., 1995; Barnes, 2000; Santti et al., 2006; Wang et al., 2008).

Compositional variations of chromite via alteration process. The distribution of minor and trace elements in zoned chromite of type I and II provides the additional evidences of intensive metamorphic alteration. It is the $\mathrm{Zn}-\mathrm{Co}-\mathrm{Mn}$ anomaly observed for cores of Al-rich zoned chromite (Fig. 4) that is supposed to be the fingerprint of amphibolite facies metamorphism (Colas et al., 2014). Zoned chromite with Al-rich cores from the studied komatiites is enriched in $\mathrm{Zn}, \mathrm{Co}, \mathrm{Mn}$, and depleted in $\mathrm{Ga}$, Ni, and $\mathrm{V}$. This pattern is similar to the minor and trace element distribution observed by Colas et al. (2014) for cores of zoned chromite from ultramafic rocks affected by amphibolite facies metamorphism.

The remarkable features of zoned chromite of type I and II from studied komatiites are high contents of $\mathrm{ZnO}(1.3-4.3 \mathrm{wt} \%)$ and $\mathrm{MnO}(0.5-2.7 \mathrm{wt} \%)$ in cores, 
which gradually decrease from the inner to outer zones of rims (Fig. 3). $\mathrm{ZnO}$ concentrations over $0.5 \mathrm{wt} \%$ in chromite are noteworthy (Wylie at al., 1987; Bjerg et al., 1993; Liipo et al., 1995; Santti et al., 2006; Saumur, Hattori, 2013; Fanlo et al., 2015), since it has been considered to be a potential vector to the $\mathrm{Cu}-\mathrm{Zn}-\mathrm{Ni}-\mathrm{Co}$ sulfide mineralization (Groves et al., 1983; Wylie et al., 1987). The Zn enrichment in chromite may be the result of recrystallization during metamorphic alteration (Barnes, 2000; Santti et al., 2006; Wang et al., 2008) or may have the primary magmatic origin (Groves et al., 1983, Liipo et al., 1995; Saumur, Hattori, 2013). The latter suggestion must be ruled out, since, as it has been shown above, the primary composition of studied zoned chromite of type I and II was significantly obliterated. The $\mathrm{ZnO}$ content in chromite over $2 \%$ is considered to be the signature of alteration in the amphibolite facies in metamorphosed mafic and ultramafic rocks including komatiites (Barnes, 2000; Santti et al., 2006). Moreover, Liipo et al. (1995) reported the high $\mathrm{ZnO}$ content (3.5\%) in cores of «unaltered» chromite from the Archean Näätäniemi serpentinite massif in the Kuhmo Greenstone Belt. According to the authors, though this chromite preserves high $\mathrm{Mg \#}(0.5-0.6)$, the high $\mathrm{ZnO}$ content to be more «result of metasomatism related to the $\mathrm{Zn}$-rich mineralization than indication of komatiitic origin». Since $\mathrm{ZnO}$ and $\mathrm{MnO}$ contents exhibit slightly positive correlation in chromite cores of type I and II $(r=0.64$ and 0.56 respectively), this conclusion points to the possibility of similar metamorphic enrichment for $\mathrm{MnO}$.

Variations of $\mathrm{NiO}$ content in studied chromite have an opposite trend, as compared with $\mathrm{ZnO}$ and $\mathrm{MnO}$, since the higher $\mathrm{NiO}$ content is observed in magnetite rims of zoned chromite than in its cores (Table 1,2). It can be caused by serpentinization of Ni-rich olivine and redistribution of $\mathrm{Ni}$ between silicate and magnetite phases during metamorphic reactions (Barnes, Kunilov, 2000).

However, some aspects of trace element behaviour in cores and rims of metamorphosed chromite might be inherited from primary chromite. The characteristic feature of the trace element distribution in zoned chromite from studied komatites is the positive Sc anomaly, which was not observed in patterns of metamorphic chromite (Colas et al., 2014; Gonzalez-Jiménez et al., 2016). Comparison of obtained data with results of the study of unmetamorphosed chromite from ophiolites (Pagé, Barnes, 2009) and komatiites (Gonzalez-Jiménez et al., 2014) shows that although the Al-rich cores of studied chromite are depleted in the most of trace elements as compared to unmetamorphosed chromite, their spidergrams are closer to chromite from ophiolite rather than one from komatiites (Fig. 4). Trace element spidergrams (Fig. 5) demonstrate the similarity of $\mathrm{Ga}, \mathrm{Ni}$, Ti, and $\mathrm{V}$ contents in the core and rims of Al-rich chromite that indicates that their distributions are not strongly modified by metamorphic alteration.

\section{CONCLUSION}

Based on microprobe and LA-ICP-MS analyses of zoned chromite from Archean komatiites in the Karelian Craton we suppose that its formation occurred during prograde metamorphism. Development of ferrian rims in studied chromite is the result of replacement of primary chromite by magnetite due to metamorphic reactions between chromite and surrounding silicates. A small miscibility gap between core and magnetite rims observed in Al-rich zoned chromite shows that the core are closed to be completely re-equilibrated with metamorphic rims. This, in 
turn, promoted the exchange of minor and trace elements between core and rims. It is evidenced by the similarity of trace element distributions in the core and rims of zoned Al-rich chromite. Since the primary composition of studied zoned chromite was significantly obliterated during metamorphism, established patterns can be used as a guide for the reconstruction of metamorphic processes.

We thank E. Hanski for the constructive comments, which helped us to improve the manuscript. Dr. T. Halkoaho is gratefully acknowledged for fieldwork support in Finland in 2014. This research was partially supported by RFBR N 17-55-45005 through the Collaboration Program between Karelian Research Centre, RAS, Petrozavodsk, Russia and Bundelkhand University, India. The financial support for the research was from the Federal budget for the implementation of the state order.

\section{References}

Abbott D. H., Isley A. E. The intensity, occurrence, and duration of superplume events and eras over geological time. J. Geodynamics. 2002. Vol. 34. P. 265-307. $466 \mathrm{p}$

Arndt N. T., Lesher C. M., Barnes S. J. Komatiite. New York: Cambridge University Press, 2008.

Barnes S. J. Chromite in komatiites. I. Magmatic controls on crystallization and composition. J. Petrol. 1998. Vol. 39. P. 1689-1720.

Barnes S. J. Chromite in komatiites. II. Modification during greenschist to mid-amphibolite facies metamorphism. J. Petrol. 2000. Vol. 41. P. 387-409.

Barnes S. J., Kunilov V. Y. Spinels and Mg-ilmenites from the Noril'sk 1 and Talnakh intrusions and other mafic rocks of the Siberian flood basalt province. Econ. Geol. 2000. Vol. 95. P. $1701-1717$.

Bjerg E. A., de Brodtkorb M. K., Stumpfl E. F. Compositional zoning in Zn-chromites from the Cordillera Frontal Range, Argentina. Miner. Mag. 1993. Vol. 57. N 1. P. 131-139.

Burkhard D. J. M. Accessory chromium spinels: their coexistence and alteration in serpentinites. Geochim. Cosmochim. Acta. 1993. Vol. 57. P. 1297-1306.

Colas V., Gonzalez-Jiménez J. M., Griffin W. L., Fanlo I., Gervilla F., O'Reilly S. Y., Pearson N. J., Kerestedjian T., Proenza J. A. Fingerprints of metamorphism in chromite: New insights from minor and trace elements. Chem. Geol. 2014. Vol. 389. P. 137-152.

Dick H. J. B., Bullen T. Chromian spinel as a petrogenetic indicator in abyssal and alpine-type peridotite and spatially associated lavas. Contrib. Miner. Petrol. 1984. Vol. 86. P. 54-76.

Farahat E. S. Chrome-spinels in serpentinites and talc carbonates of the El Ideid-El Sodmein District, central Eastern Desert, Egypt: their metamorphism and petrogenetic implications. Chem. der Erde. 2008. Vol. 68. P. 193-205.

Fanlo I., Colas V., Subias I. Zn-, Mn- and Co-rich chromian spinels from the Bou-Azzer mining district (Morocco): Constraints on their relationship with the mineralizing process. Ore Geol. Rev. 2015. Vol. 71. P. 82-98.

Gervilla F., Padrón-Navarta J. A., Kerestedjian T., Sergeeva I., Gonzalez-Jiménez J. M., Fanlo I. Formation of ferrian chromite in podiform chromitites from the Golyamo Kamenyane serpentinite, Eastern Rhodopes, SE Bulgaria: a two-stage process. Contrib. Miner. Petrol. 2012. Vol. 164. P. $643-657$.

Gonzalez-Jiménez J. M., Barra F., Garrido L. N. F., Reich M., Satsukawa T., Romero R., Salazar E., Colas V., Orellana F., Rabbia O., Plissart G., Morata D. A secondary precious and base metal mineralization in chromitites linked to the development of a Paleozoic accretionary complex in Central Chile. Ore Geol. Reviews. 2016. Vol. 78. P. 14- 40.

Gonzalez-Jiménez J. M., Locmelis M., Belousova E., Griffin W. L., Gervilla F., Kerestedjian T., O'Reilly S. Y., Pearson N. J., Sergeeva I. Genesis and tectonic implications of podiform chromitites in the metamorphosed ultramafic massif of Dobromirtsi (Bulgaria). Gondwana Research. 2015. Vol. 27. P. $555-574$.

Gonzalez-Jiménez J. M., Proenza J., Griffin W. L., Gervilla F., O'Reilly S. Y., Akbulut M., Pearson N. J., Arai S. Chromitites in ophiolites: How, where, when, why? Part I. A review and new ideas on the origin and significance of platinum-group minerals. Lithos. 2014. Vol. 189. P. 127139. 
Groves D. I., Barrett F. M., Binns R. A., McQueen K. G. Spinel phases associated with metamorphosed volcanic-type iron-nickel sulfide ores from Western Australia. Econ. Geol. 1977. Vol. 72. P. $1224-1244$.

Hanski E. Komatiitic and tholeiitic metavolcanics of the Sivikkovaara area in the Archean Kuchmo greenstone belt, eastern Finland. Bull. Geol. Soc. Finl. 1980. Vol. 52. P. 67-100.

Huhma H., Manttar I., Peltone P., Kontine A., Halkoah T., Hansk E., Hokkane T., Hölttä P., Juopperi H., Konnunaho J., Lahaye Y., Luukkonen E., Pietikainen K., Pulkkinen A., Sorjonen-Ward P., Vaasjoki M., Whitehouse M. The age of the Archaean greenstone belts in Finland. In: The Archean of the Karelia Province in Finland. Geol. Surv. Finl., 2012. p. 74-175.

Isley A. E., Abbott D. H. Plume-related mafic volcanism and the deposition of banded iron formation. Geophys. Research. 1999. Vol. 104. P. 15461-15477.

Kamenetsky V. S., Crawford A. J., Meffre S. Factors controlling chemistry of magmatic spinel: an empirical study of associated olivine, Cr-spinel and melt inclusions from primitive rocks. J. Petrol. 2001. Vol. 42. № 4. P. $655-671$.

Kozhevnikov V. N. Archean greenstone belts of Karelian craton. Petrozavodsk: IG KRC RAS, 2000. 223 p. (in Russian).

Kulikov V. S., Kulikova V. V., Buchkov Y. V. The Vetreny Belt: tectonic and petrological characteristics of Paleoproterozoic east-southern part of the Fennoscandian Shield. In: Geology of Karelia: from Archean to Present. Petrozavodsk: IG KRC RAS, 2011. p. 91-103 (in Russian).

Liipo J. P., Vuollo J. I., Nykäinen V. M., Piirainen T. A. Zoned Zn-rich chromite from the Näätäniemi serpentinite massif, Kuhmo greenstone belt, Finland. Canad. Miner. 1995. Vol. 33. P. $537-45$.

Manikyamba C., Kerrich R., Khanna T. C., Krishna A. K., Satyanarayanan M. Geochemical systematics of komatiite - tholeiite and adakitic-arc basalt associations: the role of a mantle plume and convergent margin in formation of the Sandur Superterrane, Dharwar craton, India. Lithos. 2008. Vol. 106. P. $155-172$.

Maier W. D., Peltonen P., Halkoaho T., Hanski E. Geochemistry of komatiites from the Tipasjarvi, Kuhmo, Suomussalmi, Ilomantsi and Tulppio greenstone belts, Finland: Implications for tectonic setting and Ni sulphide prospectivity. Precambrian Research. 2013. Vol. 228. P. 63-84.

Pagé P., Barnes S. J. Using trace elements in chromites to constrain the origin of podiform chromitites in the Thetford Mines ophiolite, Québec, Canada. Econ. Geol. 2009. Vol. 104. N 7. P. 9971018.

Page P., Barnes S. J., Bedard J. H., Zientek M. L. In situ determination of Os, Ir, and Ru in chromites formed from komatiite, tholeiite and boninite magmas: Implications for chromite control of $\mathrm{Os}$, Ir and $\mathrm{Ru}$ during partial melting and crystal fractionation. Chem. Geol. 2012. Vol. 302-303. P. 3-15.

Polat A., Kerrich $R$. Reading the geochemical fingerprints of Archean hot subduction volcanic rocks: evidence for accretion and crustal recycling in mobile tectonic regime. In: Archean Geodynamics and Environments. Washington: Am. Geoph. Union, 2006. P. 189-213.

Proenza J., Ortega-Gutiérrez F., Camprubi A., Tritlla J., Elías-Herrera M., Reyes-Salas M. Paleozoic serpentinite-enclosed chromitites from Tehuitzingo (Acatlán Complex, southern Mexico): a petrological and mineralogical study. J. South Amer. Earth Sci. 2004. Vol. 16. № 8. P. 649-666.

Puchtel L. S., Hofmann A. W., Mezger K. Oceanic plateau model for continental crustal growth in the Archaean: A case study from the Kostomuksha greenstone belt, NW Baltic Shield. Earth Planet. Sci. Lett. 1998. Vol. 155. P. 57-74.

Sack R. O., Ghiorso M. S. Chromian spinels as petrogenetic indicators: thermodynamics and petrological applications. Amer. Miner. 1991. Vol. 76. № 5-6. P. 827-847.

Santti J., Kontinen A., Sorjonen-Ward P., Johanson B., Pakkanen L. Metamorphism and chromite in serpentinized and carbonate-silica altered peridotites of the Paleoproterozoic Outokumpu-Jormua ophiolite belt, Eastern Finland. Int. Geol. Rev. 2006. Vol. 48. P. 494-546.

Saumur B. M., Hattori K. Zoned Cr-spinel and ferritchromite alteration in forearc mantle serpentinites of the Rio San Juan Complex, Dominican Republic. Miner. Mag. 2013. Vol. 77. N 1. P. $117-136$.

Slabunov A. I., Lobach-Zhuchenko S. B., Bibikova E. V, Sorjonen-Ward P., Balagansky V. V., Volodichev O. I., Shchipansky A. A., Svetov S. A., Chekulaev V. P., Arestova N. A., Stepanov V. S. The Archaean nucleus of the Fennoscandian (Baltic) Shield. Geol. Soc. London Memoirs. 2006. Vol. 32. P. $627-644$.

Smolkin V. F., Borisova V. V., Svetov S. A, Borisov A. E. Late Archean komatiites of the Ura Bay—Titovka Structure, northwestern Kola Region. Petrology. 2000. Vol. 8. P. 177-199.

Svetov $S$. A. Magmatic systems of ocean-continent transition zones in the Archean part of the Fennoscandian Shield. Petrozavodsk: IG KRC RAS, 2005. 230 p. (in Russian). 
Svetov S. A., Huhma H. Geochemistry and Sm-Nd systematics of the Archean komatiitictholeiitic associations of the Vedlozero-Segozero greenstone belt. Central. Doklady Earth Sci. 1999. Vol. 369. N 8. P. $1204-1207$ (in Russian).

Svetov S. A., Svetova A. I., Huhma H. Geochemistry of the komatiite-tholeiite rock association in the Vedlozero-Segozero Archean greenstone belt, Central Karelia. Geochem. Int. 2001. Vol. 39. P. $24-38$.

Svetova A. I. Archean volcanism of the Vedlozero-Segozero Greenstone Belt of Karelia. Petrozavodsk: IG KRC RAS, 1988. 148 p. (in Russian).

Vrevsky A. B. Petrology and geodynamic regimes of the evolution of Archean lithosphere (a case study of the east-northern part of the Fennoscandian Shield). Leningrad: Nauka, 1989. 143 p. (in Russian).

Wang J., Hattori K. H., Li J. P., Stern C. Oxidation state of Paleozoic subcontinental lithospheric mantle below the Pali Aike. Lithos. 2008. Vol. 105. P. 98-110.

Wylie A. G., Candela P. A., Burke T. M. Compositional zoning in unusual Zn-rich chromite from the Sykesville district of Maryland and its bearing on the origin of «ferritchromit». Amer. Miner. 1987. Vol. 72. P. $413-422$.

Zhou M.-F., Kerrich R. Morphology and composition of chromite in komatiites from the Belingwe Greenstone Belt, Zimbabwe. Amer. Miner. 1992. V. 59. P. 608-612.

Поступила в редакцию 20 февраля 2019 г. 